\title{
COMPARATIVE ANALYSIS OF QUALITY TO FORECAST MODELS OF EXCHANGE TRADED FUNDS DYNAMICS
}

\author{
Vasylieva O. V., Maksyshko N. K., Pedan D. D. \\ Zaporizhzhya National University \\ Ukraine, 69600, Zaporizhzhia, st. Zhukovsky, 66 \\ oksanabay@ukr.net, maxishko@ukr.net \\ ORCID 0000-0002-6332-2707, ORCID 0000-0002-0473-7195
}

Key words:

exchange traded fund, neural networks, time series, forecast model, forecast horizon.
The article is devoted to the comparative analysis to forecast models of exchangetraded investment funds dynamics. The exchange traded investment fund was chosen for the study as a modern investment instrument, which managed to combine the best features of stocks and mutual investment funds. However, despite the advantages of this financial instrument, the main task of the investor is the ability to predict its dynamics. To date, there are many forecast models, but the ability to create a reliable and accurate forecast remains extremely important.

Two exchange traded funds were selected for forecasting: SPDR S\&P 500 ETF TRUST (the stock ticker is SPY) and VanEck Vectors Gold Miners (the stock ticker is GDX). Based on daily prices for the period from January 2016 to January 2020, forecast models of two types were built: linear and nonlinear. Namely, linear models of moving average and exponential smoothing (Holt model) were selected. The neural network model was chosen as a nonlinear model. It turned out that the quality assessment of all models is quite high. However, the constructed forecasts showed that despite the high quality of the obtained statistical models of moving average and exponential smoothing, forecasting with their help is possible only for the forecast horizon, which is one trading day. The neural network model, conversely, shows a worse forecast for the first forecast value, but captures the dynamics and direction of price changes in both the exchange-traded investment fund SPY and GDX. That is, with the help of training, the neural network is able to establish hidden nonlinear patterns of price dynamics. But the horizon of the neural network forecast is also limited: in research it is established that the forecast on the basis of a neural network model it is expedient to build no more than for one exchange week.

\section{ПОРІВНЯЛЬНИЙ АНАЛІЗ ЯКОСТІ ПРОГНОЗНИХ МОДЕЛЕЙ ДИНАМІКИ БІРЖОВИХ ІНВЕСТИЦІЙНИХ ФОНДІВ}

\author{
Васильсва О. В., Максишко Н. К., Педан Д. Д. \\ Запорізький національний університет \\ Україна, 69600, м. Запоріжжя, вул. Жуковського, 66
}

\begin{abstract}
Ключові слова:
біржовий інвестиційний фонд, нейронна мережа, часові ряди, прогнозна модель, горизонт прогнозу.
\end{abstract}

Стаття присвячена порівняльному аналізу прогнозних моделей динаміки біржових інвестиційних фондів. Для дослідження було обрано біржовий інвестиційний фонд як сучасний інвестиційний інструмент, якому вдалося поєднати в собі найкращі риси акцій та пайових інвестиційних фондів. Однак, незважаючи на переваги цього фінансового інструмента, основною задачею інвестора залишається можливість прогнозування його динаміки. На сьогоднішній день існує багато прогнозних моделей, але можливість створення достовірного та точного прогнозу залишається вкрай актуальним.

Для прогнозування було обрано два біржовий інвестиційних фонди: SPDR S\&P 500 ETF TRUST (біржовий тікер SPY) та VanEck Vectors Gold Miners (біржовий тікер GDX). На підставі щоденних цін за період з січня 2016 року до січня 2020 року побудовано прогнозні моделі двох типів: лінійні та нелінійну. А саме, лінійні моделі - ковзного середнього та експоненційного згладжування (модель Хольта). В якості нелінійної моделі обрана нейромережева модель. Виявилося, що показники оцінки якості усіх моделей $€$ достатньо високими. Однак побудовані прогнози показали, що, незважаючи на високу якість отриманих статистичних моделей, здійснення прогнозу за їх допомогою можливе лише для горизонту прогнозу, що становить один біржовий день. Модель, побудована на основі нейронної мережі, навпаки, показує гірший прогноз для першого прогнозного значення, однак вловлює динаміку і напрям зміни ціни як по біржовому інвестиційному фонду SPY, так і по GDX. Тобто, за допомогою навчання, нейронна мережа здатна встановлювати приховані нелінійні закономірності динаміки ціни. Але горизонт прогнозу нейронної мережі теж $\epsilon$ обмеженим: в дослідженні встановлено, що прогноз на базі моделі нейронної мережі дошільно будувати не більше ніж на один біржовий тиждень. 


\section{Statement of the problem}

Stock markets are an integral part of any modern economic system, without which the efficient allocation of resources is impossible. With the development of information technology in the stock market, new modern financial instruments that meet modern requirements and demands of investors. One such tool is exchange traded funds. Exchange traded funds managed to combine the best features of stocks and mutual funds. The main advantages of exchange traded funds as a portfolio investment instrument are low commission costs, wide choice of funds by portfolio composition, low entry threshold with high diversification of the portfolio and high liquidity (investor can buy or sell the fund's shares during the exchange day). However, despite the advantages of this financial instrument, the main task of the investor is the ability to predict its dynamics.

Today, existing forecasting models can be divided into two types: linear, based on statistical methods, and nonlinear. Nonlinear models include: tree-based models, genetic algorithms, neural network models, and so on. The quality of the forecast and the investor's profit directly depend on the choice of the model type, so the assessment of the forecast quality of different types models and their comparison is an important practical task.

\section{Analysis of recent studies and publications}

Financial markets (including stock markets as their segment) in modern conditions are characterized by nonstationary, stochastic, crisis phenomena of various nature. Therefore, the question of predicting the prices movement for financial instruments in stock markets and forecasting their profitability has long been of interest to theorists and practitioners of the capital market and is relevant today.

A universal type of financial instrument such as ETF (Exchange Traded Funds) has recently appeared on the market. ETFs are a type of securities traded on an exchange and act as a certificate for a portfolio of stocks, bonds, exchange goods.

The history of ETFs began in the 1990s with the creation of a fund based on the Standard \& Poor's 500 stock index, and in 30 years they have gained considerable popularity among investors: as of 2019, there were 6,970 ETFs in the world, valued at 6.18 trillion dollars USA [1].

Currently, there are a large number of exchange traded funds that form portfolios of stocks, bonds, both in certain sectors of the economy and on regional grounds. There are even investment funds for real goods. Analysis and classification of existing exchange traded funds is given in [2]. However, there is a critique of the ETF, which is presented in [3].

Despite this, ETFs today are a universal type of investment with a low entry threshold, constant investment diversification, different directions, and so on. This type of investment is open to investors of any level and in any direction.

It should be noted that although currently this type of investment is not available in Ukraine (there is no legal regulation of ETF), but for Ukrainian investors there is an opportunity to invest in foreign ETF (open an account with a foreign broker, get a tax permit to transfer investments abroad, open a bank account for this).

The analysis of the existing methodological approaches and time series forecasting tools [4] revealed that its application for time series of price dynamics in financial markets is very limited. This is due to the fact that the hypothesis of an efficient market (corresponding to a linear paradigm) is not fulfilled for the corresponding dynamics, but such properties as fractality, persistence, presence of long-term memory corresponding to a nonlinear paradigm are revealed [5] and confirmed by the authors [6-11] and other scientists [12-13].

Therefore, the dynamics of exchange traded funds in conditions of instability requires the application of new scientifically sound forecasting tools that would take into account its features. Such studies were initiated by the authors, in particular, in [14-15] for other segments of the financial and commodity markets. This article is devoted to the study of the quality to forecasting the dynamics of exchange traded investment funds.

\section{Objective of the article}

The aim of the work is to conduct a comparative analysis to forecast models of different types (linear and nonlinear) for the dynamics of exchange-traded investment funds SPDR S\&P 500 and VanEck Vectors Gold Miners.

\section{The main material of the research}

One of the largest and the most famous investment funds is SPDR S\&P 500 ETF Trust (the stock ticker is SPY). By purchasing shares of this fund, the investor receives a balanced portfolio that replicates the set of shares and their proportions in the S\&P 500 index. The SPY structure includes the 505 largest American corporations. In order to form a similar portfolio, an individual investor will need a much larger amount of initial investment: for example, the price of one share of SPDR S\&P 500 ETF at the beginning of 2020 was approximately 325 USD, although one share of Facebook, part of the ETF portfolio, was \$ 200 USD, Microsoft share - 170 USD. And by becoming the owner of even one share of SPY, the investor has the opportunity to participate in the income from the movement of the entire American stock market.

The second exchange traded fund selected for analysis and forecasting is VanEck Vectors Gold Miners (the stock ticker is GDX). The investment portfolio of this fund consists of companies shares engaged in gold mining. The basic is the Gold Miners Index, and the shares dynamics of the exchange fund follows the dynamics of gold, but may differ due to the fact that gold mining companies are often engaged in several areas of precious metals, for instance silver or platinum. In addition, the advantage of this ETF is the ability to receive dividend income, which is excluded when trading directly in the gold market.

Gold is one of the oldest investment instruments and in times of crisis is always a "quiet haven" for investment. And with the growth of the underlying asset, the shares dynamics of gold mining companies shows outpacing growth. In addition, the exchange traded fund, in contrast to its underlying asset - gold, is characterized by high liquidity and much lower management costs $(0.51 \%)$. Besides, by acquiring shares of the GDX fund, the investor receives a high diversification for the portfolio.

The main characteristics of SPDR S\&P 500 ETF TRUST and VanEck Vectors Gold Miners are given in table 1. 
Table 1 - Main characteristics of exchange traded funds SPDR S\&P 500 ETF TRUST and VanEck Vectors Gold Miners

\begin{tabular}{|l|l|l|}
\hline \multicolumn{1}{|c|}{ ETF } & \multicolumn{1}{|c|}{ SPDR S\&P 500 ETF TRUST } & VanEck Vectors Gold Miners \\
\hline Ticker & SPY & GDX \\
\hline Management company & SPDR State Street Global Advisors & VanEck \\
\hline Object of investment & shares & shares \\
\hline Geography of investing & USA & Global \\
\hline Sector & Global & shares \\
\hline Benchmark & S\&P 500 Index & Gold Miners Index \\
\hline Fund currency & USD & USD \\
\hline Date of foundation & 22.01 .1993 & 16.05 .2006 \\
\hline Total cost ratio & $0,0945 \%$ & $0,51 \%$ \\
\hline $\begin{array}{l}\text { Market capitalization at the } \\
\text { beginning of 2020 }\end{array}$ & 296,5 billions USD & 8,2 billions USD \\
\hline
\end{tabular}

The analysis period for forecasting two exchange traded funds selected the study period: the last five years, from 2015 to January 2020. Data for analysis were obtained 350

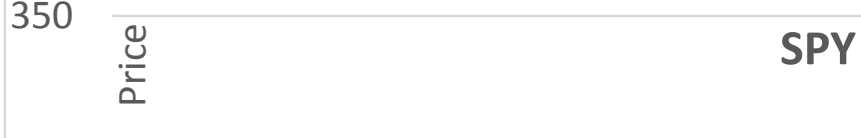

250

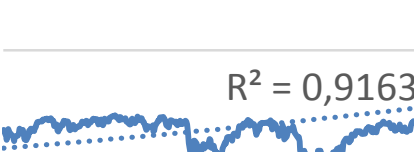

150 from the information platform for stock trading investing.com [1]. A graphical representation of the dynamics for the selected ETFs is shown in Fig. 1.

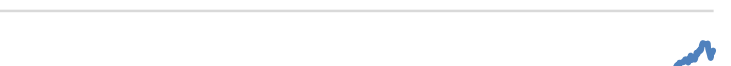

02.01 .2016

02.01.2017

02.01 .2018

02.01 .2019

Date

a)

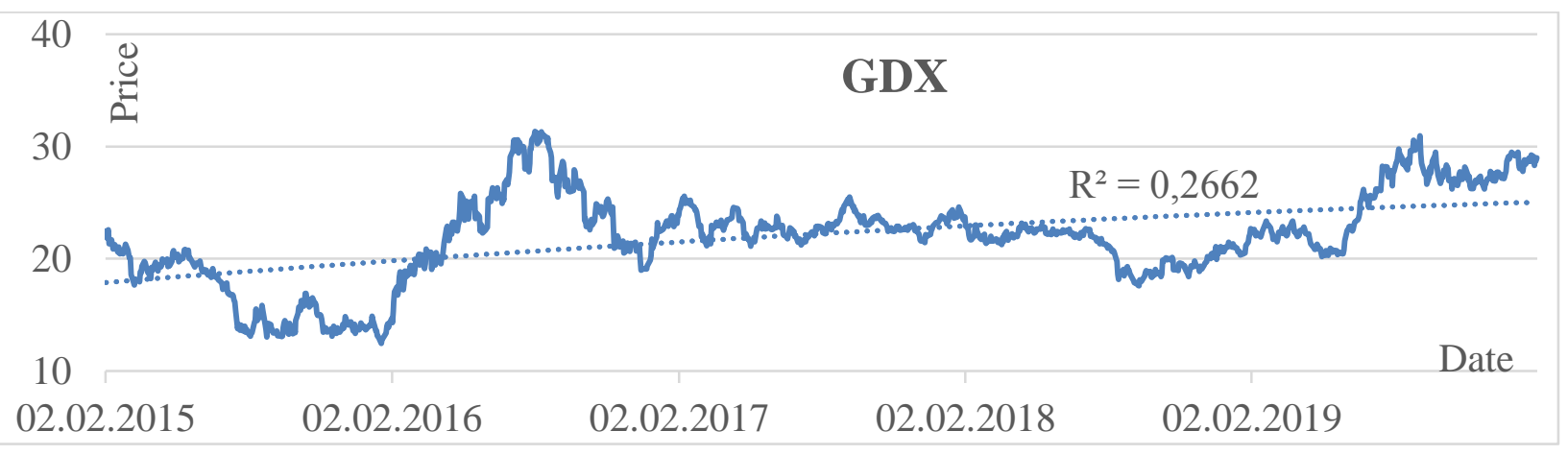

б)

Figure 1 - Dynamics of exchange traded investment funds for the period from 2015 to January 2020: a) SPDR S\&P 500 ETF TRUST (SPY); б) VanEck Vectors Gold Miners ETF (GDX)

In order to predict, the models of time series dynamics are built. Consider and compare standard statistical forecasting methods with the method of data mining, namely the neural network model. The most common and simple method of constructing a short-term forecast is the method of exponential smoothing and moving average.
Moving average (MA). To obtain a forecast by this method, the average values of previous events for a certain period must be found. The gist of this method is to assume that future events are approximately equal to the average value of past events. The main task facing the analyst is to determine the width of the window $(\mathrm{T})$, ie to determine how many previous periods will be taken into account in the calculation. 
A model of the moving average for the time series SPDR S\&P 500 using different window widths are built. A comparison of the quality indicators of each of them are shown in table 2.

Table 2 - Quality indicators of the moving average model for the time series SPDR S\&P 500 ETF TRUST (SPY) when changing the width of the window $\mathrm{T}$

\begin{tabular}{|l|c|c|}
\hline Window width & Mean absolute deviation (MAD) & Mean absolute error (MAPE) \\
\hline $\mathrm{T}=15$ & 3,36 & $1,36 \%$ \\
\hline $\mathrm{T}=5$ & 2,10 & $0,86 \%$ \\
\hline $\mathrm{T}=3$ & 1,77 & $0,72 \%$ \\
\hline $\mathrm{T}=2$ & 1,59 & $0,65 \%$ \\
\hline
\end{tabular}

The table 2 shows that when reducing the width of the window, the quality of the model improves, so for further use, determine the width of the window $\mathrm{T}=2$.

Exponential smoothing and Holt model. One of the most popular methods of short-term forecasting is the method of exponential smoothing. The gist of this method is that each element (level) of the time series is smoothed with a weighted average, and its weight decreases during the distance from the end of the series.

The main advantages of the method are the ability to account for the weights of the source information, the simplicity of computational operations, the flexibility of describing different dynamics. The basis of the method is the choice of the weight parameter $\alpha$.

When applying this method, it should be noted that the model of exponential smoothing does not take into account the presence of a trend in the series, which is a significant disadvantage for predicting the dynamics of the SPDR S\&P 500 time series, which is characterized by a pronounced upward trend. Therefore, to model the dynamics of SPY, the model of exponential Holt smoothing with a trend coefficient are used.

To determine the parameter $\alpha$, use the function MS EXCEL "Solver".

When constructing the Holt model, in addition to the smoothing coefficient $a$, it is necessary to determine the trend coefficient $t$. In this case, when searching for a solution, we set an additional variable parameter $\mathrm{t}$ and an additional constraint: $\mathrm{t} \leqslant 0$.

As a result of applying the model of exponential smoothing to the calculated data and using the tool "Solver" it is established that for the time series:

- SPDR S\&P $500 \alpha=0.78$;

- SPDR S\&P 500 (Holt model) $\alpha=0.94$;

- VanEck Vectors Gold Miners $\alpha=0.87$.

Neural network. To create a neural network and forecast based on the neural network model, we use Deductor Studio Academic business intelligence software.

To build a neural network, one of the important steps is to determine the architecture of the neural network, namely, to justify: the number of input neurons, the number of hidden layers of neurons, the number of neurons in each hidden layer. It should be noted that the definition of neural network architecture for modeling natural processes is a topical issue, the answer to which scientists and practitioners of the world engage in $[16,17]$, and is one of the crucial to create an adequate forecast model.

Given that the pre-forecast analysis of the selected time series showed the fractal nature of the dynamics (Hurst exponent $\mathrm{H}=0.94$ for both series), to determine the number of input neurons that will participate in the construction of the forecast, a sequential $\mathrm{R} / \mathrm{S}$ analysis was performed [18]. The result is a fuzzy set of memory depth (Fig. 2).

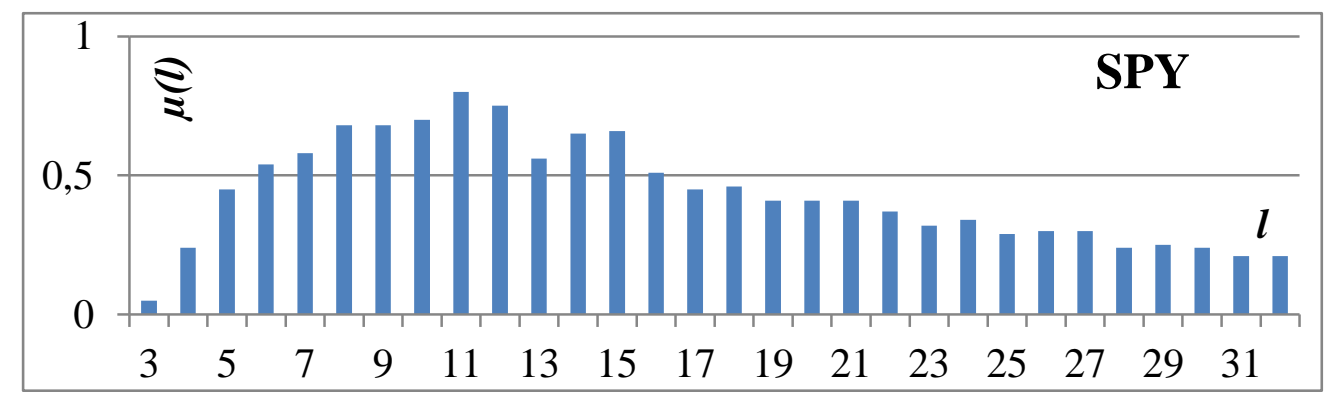

a) 


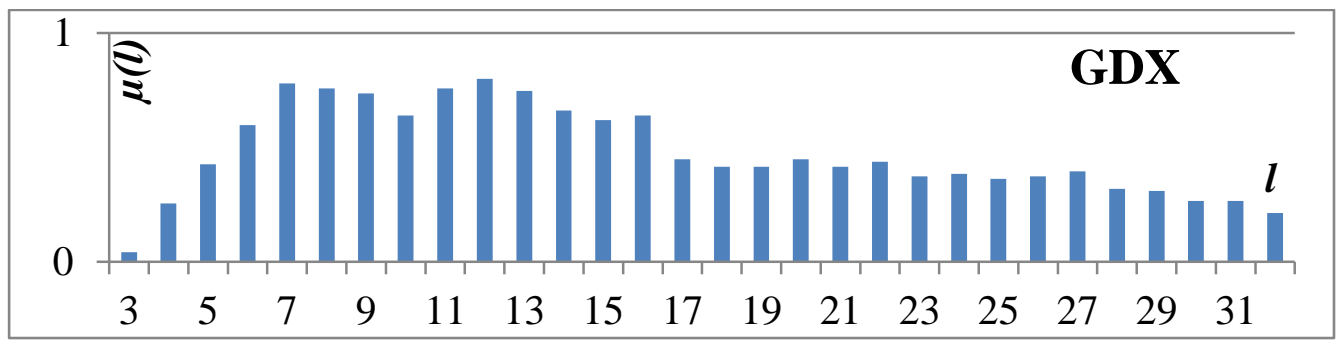

б)

Figure 2 - The fuzzy set of the time series memory depth:

a) SPDR S\&P 500 ETF TRUST (SPY); б) VanEck Vectors Gold Miners ETF (GDX)

Analyzing the resulting fuzzy set of memory depths, it should be noted that after a memory depth of 1 equal to 15 days for SPY and 16 for GDX, the significance level drops sharply to less than $0.6(\mu(1) \leqslant 0.6)$. Based on the above, we believe that the greatest impact on the next event is 15 previous events for the SPY time series and 16 previous ones for GDX. Accordingly, the number of input neurons to be used in the prediction model is 15 and 16 , respectively.

According to research [16], most processes can be modeled using a neural network with one or two inner layers. The use of 3 or more layers requires detailed justification. Given the relatively small number of input neurons, one hidden layer in creating the model is used. According to [16], a unified mechanism for determining the number of hidden layer neurons also does not exist, but often their number is approximately equal to the root of the number of input

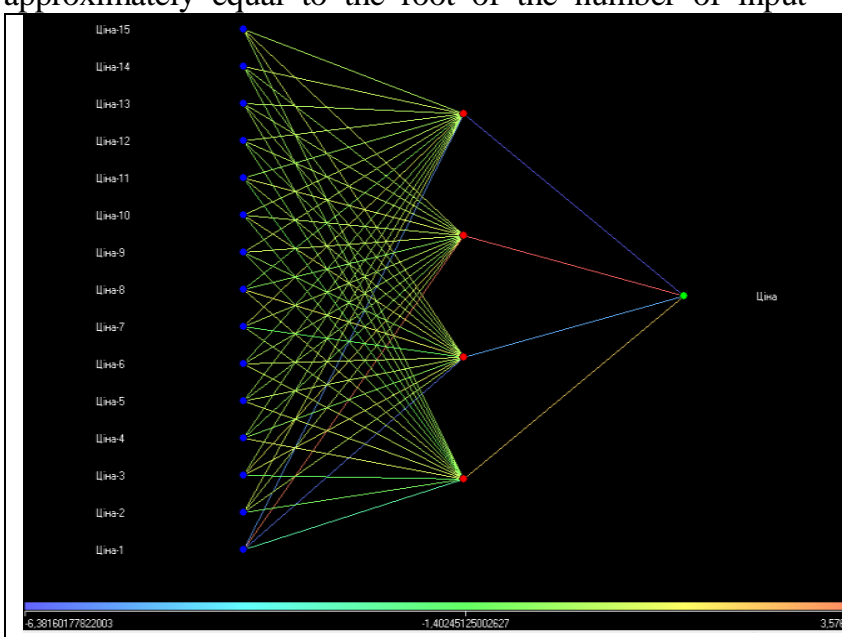

a) neurons, so the number of hidden layer neurons of the model for the exchange traded funds is defined as $4(\sqrt{ } 15 \approx 4$, $\sqrt{ } 16=4)$. To create a neural network model, the type of sigmoid function with a steepness level of 1 is used.

For the experimental learning algorithm, we choose the Resilient Propagation algorithm as faster (48 seconds compared to 26 seconds according to the Back-Propagation algorithm) and accurate. As a result, two neural network models of the dynamics for exchange traded investment funds were obtained.

Consider the architecture of the obtained models in Fig. 3. To indicate the nature of the connections between neurons, a color palette is used, according to which blue indicates the largest feedback (with a minus sign), and red - the largest direct connections.

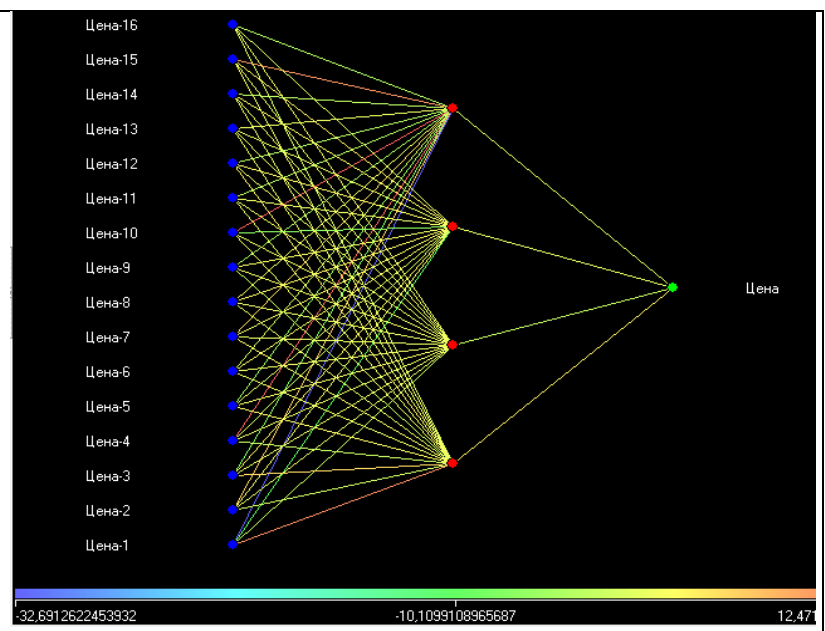

б)

Figure 3 - Graph of the neural network: a) SPDR S\&P 500 ETF TRUST (SPY);

б) VanEck Vectors Gold Miners ETF (GDX)

After analyzing the obtained graphs, we can conclude that the greatest impact on the next value of the model is the previous value, and for the time series GDX can be further allocated the fourth, tenth and fifteenth day. This pattern is explained by the five-day operation of the exchange: that is, there is some nonlinear dependence of price on the day of the week in which trading takes place. As a result of the study, statistical dynamics models based on the method of moving average, simple exponential smoothing and Holt's exponential smoothing, as well as a model of nonlinear dynamics based on a neural network for two exchange traded investment funds were built: SPDR S\&P 500 ETF TRUST and VanEck Vectors Gold Miners.
For moving average models, the width of the window (parameter $\mathrm{t}$ ) is selected, which best affects the quality of the models. For exponential smoothing models, the parameters at which it is possible to obtain the best model are also defined. The architecture building and training of the neural network were conduct. As a result, three types of models (two statistical and one neural) were obtained. From this models it is necessary to choose one that will qualitatively and accurately forecast the dynamics of selected exchange traded funds.

The quality of the obtained models is compare using the following estimates: 
- MAD (Mean Absolute Deviation) - the average absolute deviation. Measured in the same units as the elements of the time series, in this case in dollars of USA;

- MAPE (Mean Absolute Percent Error) - the average absolute error, measured in \%. Shows how significant the errors are compared to the values of the series. With this indicator comparison of different models for time series of different investment instruments is possible.

The quality estimates calculated values of the dynamics models for the exchange traded funds are given in the table 3 .

Table 3 - The errors in the dynamics model for exchange traded funds

\begin{tabular}{|l|c|c|}
\hline \multicolumn{1}{|c|}{ The applied model } & MAD & MAPE \\
\hline \multicolumn{1}{|c|}{ SPDR S\&P 500 ETF TRUST (SPY) } & $0,61 \%$ \\
\hline Exponential smoothing $(\alpha=0,78)$ & 1,47 & $0,58 \%$ \\
\hline Holt's exponential smoothing $(\alpha=0,94)$ & 1,40 & $0,65 \%$ \\
\hline Moving average (by 2 previous values) & 1,59 & $0,59 \%$ \\
\hline Neural network (structure is 15x3x1) VanEck Vectors Gold Miners ETF (GDX) & 1,45 & $1,68 \%$ \\
\hline \multicolumn{1}{|c|}{0,36} \\
\hline Exponential smoothing $(\alpha=0,87)$ & 0,38 & $1,80 \%$ \\
\hline Moving average (by 2 previous values) & 0,34 & $1,58 \%$ \\
\hline Neural network (structure is 16x3x1) & & \\
\hline
\end{tabular}

For the SPDR S\&P 500 time series, the best values of the model estimation (the smallest deviations of the forecast from the actual data) were demonstrated by the Holt exponential smoothing model, after that the neural network model follows. By taking into account the trend component of the SPY series, the Holt model significantly improved the results of the exponential smoothing model.

For the VanEck Vectors Gold Miners time series, the neural network model showed the best results. The worst results in both cases were obtained by the moving average model.

However, it should be noted that for both SPY and GDX models, the differences in model errors are insignificant: for SPY, the MAPE indicators are in the range [0.58\%;
$0.65 \%]$, and for GDX $[1.58 \% ; 1.8 \%]$. That is, all constructed models adequately describe the dynamics of time series.

Since all models have high quality indicators, we turn to the forecast of price dynamics for the periods that did not participate in the construction of the model, namely January 2020. The forecast horizon for 15 days is determined, which is equal to three exchange weeks. The definition of the horizon is taken according to the input neurons number of the neural network model: the prediction cannot exceed the time interval set at the input and is usually $30 \%$ of the input data.

In fig. 4 shows the forecast values of the price for exchange traded funds.

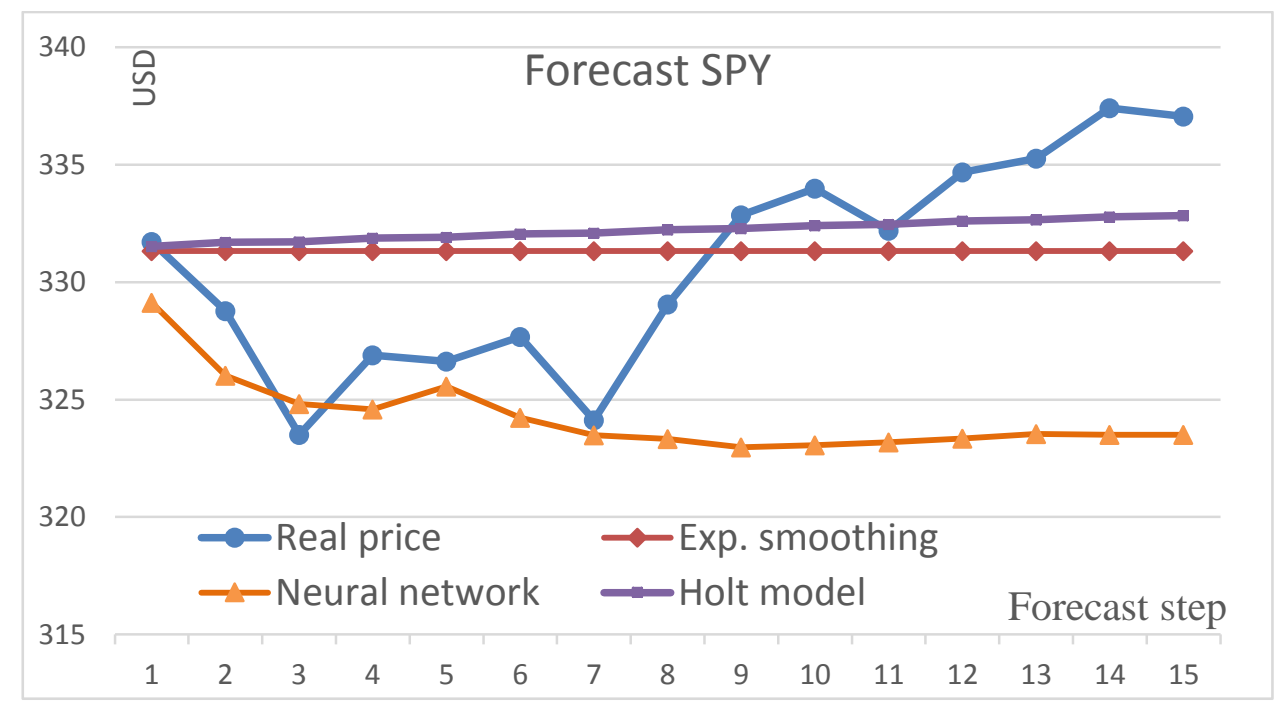

a) 


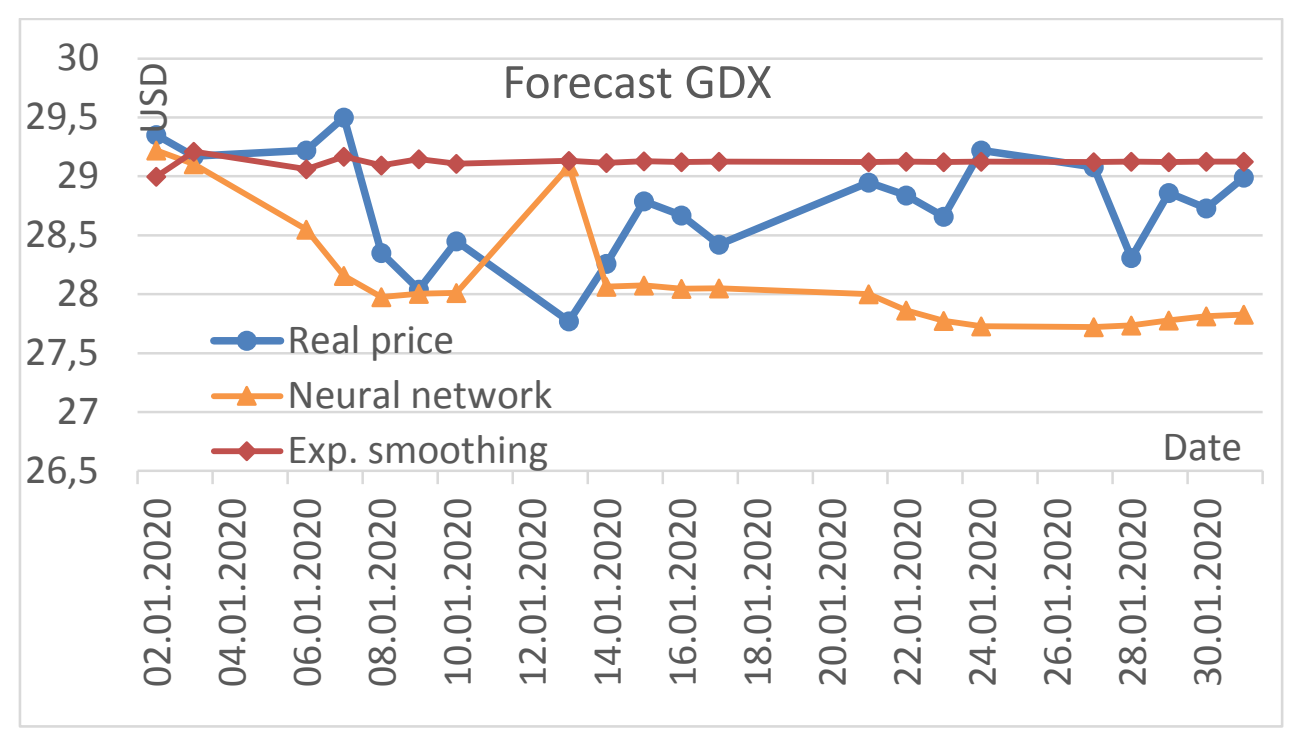

б)

Figure 4 - Comparison of the forecast for price dynamics: a) SPDR S\&P 500 ETF TRUST (SPY); б) VanEck Vectors Gold Miners ETF (GDX)

As can be seen from Fig. 4 statistical forecast models do not reflect the change in the dynamics of time series, but repeat the last value of the price (the Holt model increases it linearly according to the trend value). In contrast to statistical models, the neural network model demonstrates a change in the direction of dynamics, which copies the dynamics of the actual price of the exchange fund.

\section{Conclusions}

The following models were used to predict the dynamics of selected investment instruments (SPDR S\&P 500 and VanEck Vectors Gold Miners ETF): two statistical (moving average and exponential smoothing) and one model of nonlinear dynamics (neural network model). Given the presence of a strong upward trend for the SPDR S\&P 500 ETF time series, in addition to the standard model of exponential smoothing, a modified Holt model was used, which allows to take into account the influence of the trend on the following price values. As a result of optimum parameters selection for the applied models, the models of high accuracy are received. That is, all constructed models adequately describe the dynamics of time series.

However, the constructed forecasts showed that despite the high quality of the obtained statistical models of moving average and exponential smoothing, forecasting with their help is possible only for the forecast horizon, which is one trading day. The following forecast values do not reflect fluctuations in the price of exchange-traded instruments, but repeat the last actual value of price. The neural network model, conversely, shows a worse forecast for the first forecast value, but captures the dynamics and direction of price changes in both the exchange-traded investment fund SPY and GDX. That is, with the help of training, the neural network is able to establish hidden nonlinear patterns of price dynamics. But the horizon of the neural network forecast is also limited and after about 5-7 values attenuates and fluctuates, changing insignificantly within one level. Therefore, according to the obtained results, it is expedient to build the forecast with the help of the constructed neural network for no more than one exchange week.

\section{References}

1. Global financial portal Investing.com. ru.investing.com. Retrieved from https://ru.investing.com/ [in Russian].

2. Boyko, M.S. (2016). Birzhevyie investitsionnyie fondyi: suschnost, predposyilki zarozhdeniya, faktoryi razvitiya, klassifikatsiya [Exchange Traded Funds: essence, prerequisites for origin, development factors, classification]. Biznes v zakone. Ekonomiko-yuridicheskii zhurnal - Business-in-law. Economics and Law Journal, 3, 55-60 [in Russian].

3. Tokic, D. (2020). The passive investment bubble. J Corp Acct Fin. (Vol. 31), (pp. 7-11).

4. Geyecz, V.M., Klebanova, T.S., Chernyak, O.I., Ivanov, V.V., Kyzym, M.O., \& Dubrovina, N.A. (2008). Modeli i metody socialno-ekonomichnogo prognozuvannya [Models and methods of socio-economic forecasting]. Kharkiv: INZhEK [in Ukrainian].

5. Peters, E. (1994). Fractal Market Analysis. Applying Chaos Theory to Investment and Analysis. John Wiley \& Sons, New York.

6. Maksyshko, N., \& Vasylieva, O. (2017). Doslidzhennya dynamiky na rynku zolota: investyciinyi aspekt [Research of dynamics in the gold market: investment aspect]. Investyciyi: praktyka ta dosvid - Investment: Practice and Experience, 19, 8-15 [in Ukrainian].

7. Vasylieva, O. (2019) Comparative analysis of statistical characteristics for time-series of investment instrument prices. Bulletin of Zaporizhzhia National University. Economic Sciences, 3 (43), 49-54. 
8. Maksyshko, N., \& Vasylieva, O. (2019). Diagnostics of persistence for quotes dynamics in high-tech stock markets. CEUR Workshop Proceedings, 2422, (pp. 467-478).

9. Maksyshko, N., \& Vasylieva, O. (2019). Investigation of the markets dynamics type for a comparative analysis of the investment instruments attractiveness. Advances in Economics, Business and Management Research, 95, (pp. 335-340).

10. Vasylieva, O.V., \& Maksyshko, N.K. (2019). Porivnyalnyi analiz dynamiky investycijnyx instrumentiv u konteksti gipotezy efektyvnogo rynku [Comparative analysis of the dynamics of investment instruments in the context of the efficient market hypothesis]. Naukovi zapysky Nacionalnogo universytetu «Ostrozka akademiya». Seriya «Ekonomika» - Scientific notes of the National University «Ostroh Academy». Economics Series, 12(40), $200-206$. [in Ukrainian].

11. Maksyshko, N., Vasylieva, O., Kozin, I., \& Perepelitsa, V. (2020). Comparative analysis of the attractiveness of investment instruments based on the analysis of market dynamics. Machine Learning for Prediction of Emergent Economy Dynamics 2020. CEUR Workshop Proceedings, 2713, 219-238. Retrieved from http://ceur-ws.org/Vol2713/paper18.pdf.

12. Soloviev, V., \& Belinskij, A. (2018). Methods of nonlinear dynamics and the construction of cryptocurrency crisis phenomena precursors. CEUR Workshop Proceedings, 2104, 116-1270.

13. Soloviev, V., Serdiuk, O., Semerikov, S., \& Kohut-Ferens, O. (2019). Recurrence entropy and financial crashes. Advances in Economics, Business and Management Research, 99, 385-388. Retrieved from doi:10.2991/mdsmes19.2019.73.

14. Maksyshko, N., Vasylieva, O., Cheverda, S., \& Basova, D. (2019). Porivnyalnyi analiz yakosti prognoznyh modelej dynamiky finansovyh instrumentiv $\mathrm{z}$ uraxuvannyam glybyny pamyati [Comparative analysis of the quality of predictive models of the dynamics of financial instruments, taking into account the depth of memory]. O. I. Chernyak, \& P.V. Zakharchenko (Eds), Aktualni problemy prognozuvannya rozvytku socialno-ekonomichnyh system - Actual problems of forecasting the development of socio-economic systems, (pp. 127-133). Melitopol : Vyd. Dud. [in Ukrainian].

15. Cheverda, S., \& Maksyshko, N. (2020). Forecast research of dynamics of world oil prices based on complex fractal analysis. Bulletin of Zaporizhzhia National University. Economic Sciences, 1 (45), 62-68.

16. Chernyak, O. I., \& Zakharchenko, P. V. (2010). Intelektualnyi analiz danyh [Data mining]. Kyiv: Znannia [in Ukrainian].

17. Ryepka, V. B. (2010). Osnovni polozhennya shtuchnyh nejronnyh merezh [The main provisions of artificial neural networks]. Kharkiv: NURE. Retrieved from https://dl.nure.ua/pluginfile.php/634/mod_resource/content/2/001.pdf [in Ukrainian].

18. Maksyshko, N. K. (2009). Modelyuvannya ekonomiky metodamy dyskretnoyi neliniynoyi dynamiky [Modeling of economy by discrete nonlinear dynamics methods]. V.O. Perepelytsya (Ed). Zaporizhzhia: Polihraf [in Ukrainian]. 